\title{
W poszukiwaniu terminologii językoznawczej: system w czasach symbolu czy symbol na potrzeby systemu?
}

\section{Przemysław Lozowski}

Uniwersytet Marii Curie-Skłodowskiej w Lublinie lozowski.przemyslaw@poczta.umcs.lublin.pl

\section{Streszczenie}

Zakładamy, że terminologia naukowa powinna odzwierciedlać „,ducha czasu”, tj. panujaca aure intelektualna. Te obecna określamy jako postmodernistyczna i identyfikujemy $z$ poszukiwaniami subiektywności osadzonych $w i$ motywowanych przez kontekst doświadczeniowy człowieka. Stwierdzamy, że terminologia autonomicznych koncepcji języka rozmija sie z obecnym ,duchem czasu”, a terminologia propozycji integracyjnych nie jest dostatecznie konsekwentna i przejrzysta.

Stowa kluczowe: terminologia, definicja, metafora, symbol, system

Abstract

In Search of Linguistic Terminology: System in Times of Symbol or Symbol for the Sake of System

In the article, we claim that scientific terminology should keep abreast of the times it serves. We identify the current intellectual climate as post-modernistic in the sense that general principles cannot be evaluated out of the spatiotemporal context in which they were initially proposed. Against that background, the terminology of autonomous linguistics must be said to be no match for the present spirit of the times, while the terminology of non-autonomous linguistics lacks at times precision and common sense.

Keywords: terminology, definition, metaphor, symbol, system

\section{Wstęp}

W wypowiedzi zwracamy uwagę na dwie przyczyny, dla których terminologia językoznawcza utrudnia percepcję nauki o języku. Pierwsza przyczyna ma związek z tezą, że żeby coś było 
zrozumiałe i stało się bliskie, powinno być wyrażone w kategoriach właściwych dla panującej aury intelektualnej, przeważającego klimatu poznawczego, podzielanej wrażliwości, obowiązującej umysłowości. Innymi słowy, jeżeli opis danego zjawiska w postaci rygorów terminologii naukowej/badawczej napotyka na trudności, opór i sprzeciw tych, do których (ten opis) jest adresowany, to dlatego, że nie tylko nie spotyka się z poznawczym doświadczeniem odbiorcy, ale jest wręcz przeciw temu doświadczeniu wymierzony. Próba organizowania społeczeństwa na zasadach teokracji w czasach demokracji, czy zakusy nacjonalizacji w dobie prywatyzacji, to nie tylko nieporozumienie, ale także zagrożenie. Mówienie i pisanie o języku tak, jak to się na ogół dzisiaj czyni, jest nie tylko anachroniczne, ale i niepokojące.

Drugi powód, dlaczego - jak twierdzę - językoznawstwo nastręcza dzisiaj nam (językoznawcom) trudności dydaktycznych, a im (studentom) trudności poznawczych, jest taki, że nawet jeśli terminologia już wyraża ,ducha czasu”, to jeszcze musi to czynić w sposób konsekwentny, budować czytelne odniesienia, i pozostawać w zgodzie ze zdrowym rozsądkiem. Innymi słowy, trudność polega na tym, że stosunkowo łatwo jest pozować na językoznawczy „duch czasów”, a w istocie albo przemycać stary aparat pojęciowy za pomocą nowej terminologii, albo nowy aparat ubierać w starą terminologię, w obu przypadkach zdradzając mentalność poprzedniej epoki. Tym razem moglibyśmy powiedzieć, że budowa tzw. kapitalizmu politycznego na zasadzie uwłaszczenia nomenklatury to tylko kryptokomuna, a publiczne wyznania celebrytów, jakich kosmetyków najchętniej używają, to wciąż kryptoreklama.

\section{Lingwistyczna definicja języka na miarę czasów}

Oczywiście, żeby stwierdzić, na czym ten anachronizm i to zagrożenie polegają, należy najpierw scharakteryzować „ducha czasów”, w których przyszło nam dzielić się naszymi językoznawczymi pasjami. Myślę, że istnieje zgoda co do tego, by poznawcze doświadczenie współczesnego człowieka wiązać z postmodernizmem, a definiować ten ostatni na przykład tak, jak Harvey (1989; w Mairal i Gil 2006: 1; ten i inne cytaty anglojęzyczne podajemy we własnym thumaczeniu):

Poglądy, które obecnie cieszą się największym powodzeniem [...], to te, które przypisują większe znaczenie partykularyzmowi i fragmentacji, które skupiają które ostatecznie prowadzą do dysartykulacji i dekonstrukcji wszelkich ludzkich socjokulturowych i ekonomicznych poczynań, [...] które głoszą brak reguł ogólnych, jakie rzekomo miałyby podlegać ocenie obiektywnej, niezależnej od kontekstu czasoprzestrzennego, w którym się kiedyś pojawiły. 
Podobną myśl formułuje Szacki (1984: 10-12) i Furdal (2000: 16-17)). Ten pierwszy, gdy stwierdza, że ma miejsce ,rewizja [...] stereotypu społeczeństwa tradycyjnego [...] w stanie unieruchomienia i harmonii wewnętrznej”, co skutkuje tym, że tradycja jawi się jako „zbiór alternatyw”, a nie „pozbawiony pęknięć system wartości”, a ten drugi, gdy „otwiera” językoznawstwo na głosy z innych dziedzin humanistyki:

Wprowadzenie do nauki o języku pojęcia systemu [...] uściśliło niepomiernie wyniki badań lingwistycznych. [...] To znakomite [...] zalecenie metodologiczne kryło jednak w sobie zalążki poważnego niebezpieczeństwa. [...] [W]yodrębnianie faktów jednego typu i wyszukiwanie wśród nich struktury $[\ldots]$ grozi $[\ldots]$ izolacjonizmem badawczym. $[\ldots][\mathrm{N}]$ ie jest to zjawisko pożądane. [...] [C]zasy, w których żyjemy, mamy chyba prawo nazwać początkiem okresu integracji nauki.

A zatem, jeżeli mielibyśmy preparować opis języka na miarę czasów, to powinien on być nasycony takimi terminami jak dekonstrukcja, indywidualizm, jednostkowość, czastkowość, celowość, względność, subiektywność, kontekstowość, czasoprzestrzenność, konieczność, dynamizm, lokalizm, i inne, wszystkie w opozycji do takich pojęć, jak system, systemowość, autonomiczność, modularyzm, strukturalizm, generowanie, derywowanie, itd.

\section{1. „Systemowy” język autorów wstępów do językoznawstwa w języku angielskim}

Powinien, ale nie jest. Już pobieżna lektura samych definicji języka pod kątem stosowanej terminologii dowodzi, że autorzy wstępów do językoznawstwa opowiadają bajkę nie z tej ziemi, lub - przy najmniej - nie dla tych czasów. W prawdopodobnie najpopularniejszym wstępie do językoznawstwa w języku angielskim, Fromkin i in. (2010: 28; wyd. 9) stwierdzają, że "język [...] jest systemem, który wiąże dźwięki [...] ze znaczeniami. [...] Dźwięki i znaczenia [...] zostają połączone w sposób dowolny”. Termin system nie schodzi z kart podręcznika wszystko w języku jest systemem, a sam język jawi się jako swoisty system (pod)systemów ${ }^{1}$. A ponieważ w systemie - z zasady - nie ma nic naturalnego, niczego zdrowo-rozsądkowego, niczego, co by miało swoją przyczynę i racjonalną podstawę istnienia, to i opis systemu może być również dowolny. I tak, charakterystykę języka można rozpocząć od fonetyki, przejść do fonologii, morfologii, składni, i skończyć na semantyce (jak w pierwszych wydaniach podręcznika), ale można (jak w wydaniach nowszych) rozpocząć od morfologii, przejść do składni, później do semantyki, dalej fonetyki, i wreszcie zwieńczyć opisowy wysiłek fonologią, lub - jak w pokrewnym podręczniku autorstwa Akmajiana i in. (2010; wyd. 6) i sygnowanym przez sam Massachusetts Institute of Technology - zacząć od morfologii, przejść kolejno do systemu fonetycznego, fonologicznego, składniowego, i skończyć na semantycznym. W końcu w 
języku jako systemie nie liczą się ludzie, ale relacje, zasady, reguły, wszystkie generowane przez i derywowane z mózgu wyabstrahowanego i wyidealizowanego mówiącego-słyszącego, który dla dobra nieskrępowanego i skutecznego opisu systemu najlepiej gdyby był głucho-niemy.

\section{2. „Systemowy” język autorów wstępów do językoznawstwa w języku polskim}

Równie „systemowy” jest język dla autorów najpopularniejszych wstępów do językoznawstwa w języku polskim. W większości z nich widać wyraźnie stanowisko wypracowane przez Milewskiego (tu: 2004: 20), dla którego język to kod (system znaków) sygnałów (znaki zarówno dla nadawcy, jak i odbiorcy) semantycznych (znaki odnoszące do zjawisk otaczającego nas świata), arbitralnych (znaki, które wiążą się z treścią dzięki korelacji już dawniej istniejącej), dwuklasowych (znaki, których liczba w systemie jest nieograniczona) i fonemowych (znaki, których forma składa się z fonemów). I tak, Łuczyński i Maćkiewicz (2006: 17) definiują język następująco:

Język to system przekazywanych kulturowo sygnałów konwencjonalnych [tj. znaków dwustronnych; dla odbiorcy i nadawcy] służących do porozumiewania się w obrębie danej społeczności. Jest to kod dwuklasowy i semantyczny, cechujący się autonomicznością i kreacyjnością.

A zatem język jest jak kod Morse'a - stanowi system znaków, z których każdy jest autonomiczną kreacją (raczej: projekcją) reguł przyporządkowujących składniki sygnałów składnikom wiadomości. W taki sam sposób, jak w kodzie Morse'a nie ma racjonalnego wyjaśnienia, dlaczego literze $S$ przyporządkowana jest kombinacja trzech kropek, a literze $O$ kombinacja trzech kresek, nie ma racjonalnego wyjaśnienia dla związków form i treści w języku. System - słowo-klucz w tej definicji - to ,zbiór elementów zorganizowanych w taki sposób, że każdy element pozostaje w związku z innymi elementami i z całością, w której spełnia określone funkcje” (str. 11). O tym, by o tym sposobie zorganizowania i o tych funkcjach miały decydować parametry poza- i ponadsystemowe, mowy nie ma. Jak pisze Furdal (2000: 71-72), „[druga najważniejsza cecha znaku językowego to] „konwencjonalność, zwana nieraz arbitralnością”, co polega na tym, że „więź łącząca treść i formę znaku nie jest niczym umotywowana, czyli nie ma racjonalnego uzasadnienia”. Grzegorczykowa (2007: 24) dodaje: „,Języki] przekazywane są z pokolenia na pokolenie jako systemy znaków arbitralnych, w których brak związków między formą i znaczeniem"'2.

Snujemy zatem nasz językoznawczy dyskurs niezmiennie $\mathrm{w}$ terminach autonomicznego systemu znaków dowolnych, w którym mówiący liczy się o tyle, o ile liczy się szachista w szachach albo żołnierz w armii - wszyscy muszą się wyuczyć zamkniętego systemu reguł i 
pozostawać im wierni i lojalni do końca życia, o ile ten pierwszy chce wypowiadać zrozumiałe wyrażenia, ten drugi przesuwać figury na szachownicy, a ten trzeci doczekać awansu i emerytury.

\subsection{Ponad-i pozasystemowe symbole}

Tyle za zamkniętymi drzwiami i zasłoniętymi oknami językoznawczych pracowni. A co za nimi? Za nimi wolny świat odprawia kolejne systemy, powoli zapominając o tym, że Europa przypominała kiedyś szachownicę zantagonizowanych państw (niczym opozycja między dźwięcznym /b/ i bezdźwięcznym /p/), że Żelazna Kurtyna między wschodem i zachodem była tak wyraźna i niewzruszona, jak granica między językową formą i treścią, kompetencją i performancją, synchronią i diachronią, albo między poszczególnymi podsystemami języka fonetyką i fonologią, składnią i semantyką, semantyką i pragmatyką, itd. Językoznawcy zdają się nie zauważać, że przy definiowaniu wspólnotowych tożsamości systemowe opozycje ustępują miejsca podzielanym symbolizacjom i konceptualizacjom, że od tego, że Karol Wojtyła, Lhamo Thondup, Barack Obama są projekcją właściwych im systemów (odpowiednio jako papież Jan Paweł II, XIV Dalajlama Tenzin Gjaco, 44. prezydent Stanów Zjednoczonych), ważniejsze jest to, że funkcjonują jako ponad- i pozasystemowe symbole ludzkich dążeń i tęsknot - solidarności, wolności, pokoju, że małżeństwo dla wielu przestało być binarną relacją systemową typu męski-żeński, a jawi się coraz częściej jako całkowicie pozasystemowy symbol związku dwojga ludzi. (Por. Łozowski, w druku.)

I oto w czasach, kiedy pękają systemy i budzą się samo-świadomości (narodowe, rasowe, seksualne, pokoleniowe, kulturowe), przeważająca część językoznawców żyje w czasach Muru Berlińskiego i Żelaznej Kurtyny, prowadząc swój ogląd języka z tak „wysokiej” perspektywy, że dostrzega w języku jedynie niczym niezmącony ład i porządek doskonałego systemu. Jak pilot, który z okna samolotu granicę między ziemią i morzem - nawet przy największym sztormie, czy nawałnicy - widzi jako grubą kreskę oddzielającą dwa całkowicie niezależne, wyizolowane, i w pełni zrównoważone całości.

\subsection{Język jako doświadczenie}

Przeważająca część, ale nie wszyscy. Obok i wśród „systemistów” językoznawstwa uczy spore już grono „symbolistów” (funkcjonalistów, kognitywistów). Ci w miejsce terminologii właściwej dla opisu języka jako systemu formalnych relacji stosują terminologię odpowiednią dla charakteryzacji języka jako symbolu ludzkiego doświadczenia. Dla nich język jest - a może to ja chciałbym, żeby był - nieokiełznanym żywiołem ludzkiego poznania, zapisem świadomości użytkowników języka, wypadkową ich napięć poznawczych, probierzem 
symbolizacji ludzkiego doświadczenia, którego nie ujarzmi, nie zamknie, i nie ograniczy żaden system, ani preskryptywny ani deskryptywny. Stąd pierwszorzędna rola takich terminów jak metafora, polisemia, stereotyp, prototyp, realizm doświadczeniowy, poznanie.

\subsection{Językoznawstwo ,symbolistyczne" a ,systemiczne"}

Ale, jak piszemy na początku, uwolnić terminologię językoznawczą od kaftana systemowości, izolacjonizmu, modularyzmu, i spowić urokiem, powabem, i tajemnicą symbolizacji to jedno, a czynić to w sposób konsekwentny, przyjazny, niedogmatyczny, systematyczny, ale nie systemowy, to drugie. Odnosimy wrażenie, że wprawdzie językoznawstwo „symbolistyczne” bez wątpienia porywa bardziej niż „systemiczne”, zdecydowanie lepiej wyraża mentalność współczesnego człowieka, i bez oporów idzie $\mathrm{z}$ duchem czasów, niemniej ciąży ku terminologii, która jeśli jeszcze nie teraz, to już niebawem, z pewnością ograniczy badawcze horyzonty.

Jeden znaczący przykład w tym względzie. Ronald Langacker, czołowy kognitywista, powtarza od lat, że “język w swojej naturze jest symboliczny [i] udostępnia użytkownikowi języka - dla jego indywidualnych [personal] bądź komunikatywnych potrzeb - otwarty zbiór znaków językowych lub wyrażeń, z których każde przyporządkowuje pewnego rodzaju reprezentację semantyczną reprezentacji fonologicznej" (Langacker, 1987: 11). Co więcej, jak dodaje, „Kognitywiści i funkcjonaliści dowodzą, że pod względem [funkcji języka i jego biologicznych, poznawczych i społeczno-kulturowych uwarunkowań] w zasadzie wszystko w języku ma swoją przyczynę (nawet jeśli bardzo niewiele daje się przewidywać w sposób ścisły)" (Langacker, 2008: 1-10). Można by więc oczekiwać, że zastosowana terminologia w znaczącym stopniu zostanie pozbawiona arbitralności i odda swoje zdrowo-rozsądkowe umotywowanie. Jest inaczej. Wiele terminów nie zgadza się z, powiedzmy, prymarną intuicją użytkownika języka angielskiego, a niektóre są wręcz przeciwne ich instynktownemu odczytaniu.

I tak, rozumienie, jakie Langacker przypisuje terminowi prototype 'prototyp' (tym razem zgodnie $\mathrm{z}$ całą tradycją teorii prototypów), jest takie, że termin ten nie oznacza pierwszego/pierwotnego przedstawiciela danej kategorii, ale przedstawiciela najlepszego. Gdybyśmy więc intuicyjnie zastosowali termin prototyp do poszukiwań pierwowzoru, czy praprzykładu, homo sapiens, nie mógłby nim zostać nikt z nas, ale mógłby nim być neardentalczyk, jeśli to jego uznamy za pierwszego człowieka myślącego. Podobnie prototypem kategorii PTAKI musiałby zostać - w myśl jednej z teorii o pochodzeniu ptaków - archeopteryks, pochodna dinozaura teropoda, a nie żaden wróbel, szpak, czy gołąb. 
Wysiłku poznawczego wymagają również dwa terminy pokrewne landmark i trajektor. Główne znaczenie tego pierwszego w języku angielskim to 'punkt orientacyjny', 'moment/punkt przełomowy/zwrotny', co sugeruje prymarne znaczenie tego, co się określa jako landmark. Dla Langackera tymczasem jest to zaledwie drugoplanowy uczestnik sytuacji. W zdaniu Lampa jest nad stołem, landmarkiem jest więc nie lampa, chociaż to ona może nam się wydawać być godna miana landmarku jako centralny element sytuacji, ale stół. Lampa rzeczywiście jest prymarną figurą tutaj, ale Langacker nazywa ją trajektorem, czyli czymś, co w intuicyjnym odczytaniu powinno znajdować się w ruchu po orbicie. Cała sytuacja jest statyczna - lampa jest nad stołem, ale Langacker każe nam tu widzieć pewien ruch poznawczy. Po zapoznaniu się z jego argumentacją stwierdzamy, że ma rację, ale intuicyjnie tego odkryć się nie da.

Arbitralność terminologii Langackera ma niekiedy związek z większą grupą nazw. Na przykład, istnieje w terminologii Langackera gra słów między 3 pokrewnymi terminami: ground, grounding, oraz background. Pierwszy pojawia się w relacji do figure, co podpowiada konfigurację percepcyjną znaną z psychologii postaci jako układ figura-tło. Właśnie jako tło termin ground jest oddawany w tłumaczeniach prac Langackera, mimo, że zrozumieć go w ten sposób bez kontekstu nie sposób, bowiem w pierwszym rzędzie ma znaczenia takie, jak 'płaszczyzna ziemi', 'grunt', 'teren', 'gleba', i sugeruje relację wertykalną, a nie horyzontalną (może tylko w peryferyjnych odniesieniach do malowania i kolorowania uznamy, że ground to 'tło' w tym sensie, że jakiś wzorek (design) występuje na jakimś tle (ground)). Co do tego, że ground ma znaczyć ‘łło’, Langacker nie pozostawia wątpliwości: „, Dla określenia nadawcy i odbiorcy zdarzenia mownego, w którym uczestniczą, oraz towarzyszących temu bezpośrednich okoliczności (takich jak czas i miejsce wypowiedzenia) używam terminu [ground, 'tło']”, i podaje przykłady: „na tle ciszy [ground] nagle daje się słyszeć krzyk [figure], albo na stabilnym tle ekranu komputera [ground] porusza się mały kursor [figure]"3.

Sytuacja się komplikuje, kiedy Langacker wprowadza rozróżnienie na foreground/background (2008: 3-3): „,[O]gniskowanie [jako wymiar obrazowania] obejmuje selekcję treści konceptualnej dla celów prezentacji językowej oraz konfigurację tej treści w postaci, używając metafory, rozróżnienia na [foreground] i [background]". Wszelkie definicje słownikowe, jak i zdrowy rozsądek, podpowiadają, że background należałoby tłumaczyć jako tło, przez co mielibyśmy dwa angielskie terminy, ground i background, oddawane tym samym terminem polskim, tło. To burzyłoby intencję Langackera, by została zachowana różnica 
między ground i background. Stąd rozwiązanie (w polskich przekładach), by to pierwsze tłumaczyć jako tło, a to drugie jako plan dalszy/drugi.

Jeszcze więcej komplikacji na linii terminologia vis-a-vis zdrowy rozsądek wprowadza termin grounding, który Langacker wiąże z ground, ale już nie z background i foregrounding, i rozumie jako związek między tłem (ground, szerszy kontekst wypowiedzenia) a profilem danego wyrażenia w odniesieniu do domen kognitywnych. Tłumaczymy grounding jako (za)kotwiczenie, rozumiejąc, że wyrażenia językowe zostają „zakotwiczone”, osadzone, czy „uziemione”, w rzeczywistości. I tak, wyrażenie boy like girl ‘chłopak lubić dziewczyna' jest wyrażeniem niezakotwiczonym, ale the girl likes that boy 'ta dziewczyna lubi tego chłopaka', czy this girl may like some boy 'ta dziewczyna może lubić jakiegoś chłopaka', czy some girl liked this boy 'jakaś dziewczyna lubiła tego chłopaka', już tak, dzięki obecności elementów kotwiczących w postaci przedimków, zaimków, czasów, itp. Zakotwiczenie (grounding) ma więc miejsce $\mathrm{w}$ tle (ground), a to niełatwo sobie wyobrazić, bowiem nie da się w języku polskim czegokolwiek zakotwiczyć w tle inaczej niż w sposób arbitralny. Zamiast kotwiczenia moglibyśmy tłumaczyć grounding jako uziemianie, ale wtedy ground musiałby być ziemia, a na to nie pozwalają przykłady tego, co Langacker rozumie przez ground.

\subsection{Potrzeba postmodernistycznej definicji języka. Istniejące propozycje metodologiczne}

W obliczu powyższych uwag, nasuwa się wniosek, że potrzebna jest konsekwentna postmodernistyczna definicja języka jako symbolu ludzkiego doświadczenia (nie: systemu znaków wolnych od doświadczenia człowieka). Nie należy jednakże przeceniać roli terminologii w kreowaniu paradygmatów językoznawczych - doświadczenie pokazuje, że o sukcesie i popularności teorii nie decyduje doprecyzowana terminologia, ale genialność zamysłu badawczego, zawsze „na miarę czasów” i „z duchem czasu”. Trudno się oprzeć wrażeniu, że w propozycjach metodologicznych Saussure'a, Chomsky’ego, czy Lakoffa, nie kryje się odczytanie atmosfery umysłowej ich czasów. Przypomnijmy. W przededniu trwogi, chaosu, i pożogi I wojny światowej Ferdynand de Saussure proponuje bezwzględny, ,żelazny”, i autonomiczny porządek i ład systemu synchronicznego (tu i teraz), a wszystkim tym, którzy chcieliby poza tym systemem lokować swoje badawcze zainteresowania, dedykuje następującą przestrogę: 
Można (...) toczyć spory na temat, czy monogamiczna forma małżeństwa jest bardziej racjonalna niż poligamiczna, i przytaczać dowody na poparcie jednej lub drugiej tezy. Można by w ten sposób poddać dyskusji jakiś system symboli, gdyż symbol ma racjonalny związek z rzeczą, którą oznacza (...); dla języka jednak - systemu znaków dowolnych - brak tej bazy, a wraz z nią tracimy cały pewny grunt stanowiący podstawę dyskusji (...)”. (Saussure 1991: 97).

Równie bezdyskusyjnie trafna okazała się myśl Chomsky’ego, by język porównać do generatora, czy - jak dzisiaj pewnie byśmy powiedzieli - do komputera. Że, w uproszczeniu, oczywiście, język to twardy dysk (struktura głęboka), z którego procesor (transformacje) generuje na ekranie monitora (struktura powierzchniowa) nieskończony zbiór zdań. I to wszystko w połowie lat 50., czyli wtedy, gdy pierwsze komputery elektroniczne miały rozmiary wielkich szaf, jeśli nie całych pomieszczeń, i niewiele wskazywało na to, że myślenie w kategoriach dysk-procesor-monitor zawładnie naszą wyobraźnią niepodzielnie! Jeżeli generatywistyczna propozycja Chomsky’ego dzisiaj już nie zachwyca, to między innymi dlatego, że postrzeganie czegokolwiek (w tym: język) w kategoriach funkcjonowania komputera wydaje się tak banalnie oczywiste, że ani nie inspiruje ani nie rozbudza badawczej ciekawości. Inspiruje i rozbudza natomiast ciągle jeszcze ta myśl Johnsona i Lakoffa, by w języku widzieć wielką metaforę, w której jedne (bardziej abstrakcyjne) domeny ludzkiego bytowania zostają wyrażone w postaci innych (bardziej konkretnych) domen ludzkiego bytowania.

\section{Wnioski}

Czas pokaże, czy kiedykolwiek zdecydujemy się powiedzieć studentom, że język jest po prostu symbolem doświadczenia człowieka, tak, jak symbolem związku małżeńskiego jest pierścionek, symbolem sprawiedliwości waga, a symbolem Polski biały orzeł. Że język jest taki, jakie były, są, i będą ludzkie zachwyty i fobie, prawdy i fantazje, marzenia i zwidy, zadziwienia i uprzedzenia, nadzieje i rozpacze, wiary i niewiary (por. Łozowski 2008: 435).

\section{Przypisy}

\footnotetext{
${ }^{1}$ Podobnie w równie popularnym wstępie do językoznawstwa George’a Yule’a (2010, wyd. 4), termin system pojawia się ponad 50 razy, a rozdział o składni rozpoczyna się anegdotą, która niedwuznacznie sugeruje porównanie języka
} 
do układu słonecznego (ang. solar system), w którym ciała niebieskie poruszają się w wyłącznej i wzajemnej relacji do siebie samych.

${ }^{2} \mathrm{O}$ tym, że konwencjonalność języka nie oznacza automatycznie i wyłącznie dowolności/arbitralności znaków językowych, jak to sugeruje przeważająca część językoznawców, piszę w Łozowski (2006).

${ }^{3}$ Wypowiedziom tym towarzyszy jednakże zastrzeżenie, że chociaż ground $\mathrm{w}$ odniesieniu do figure i ground $\mathrm{w}$ odniesieniu do tła sytuacyjnego to znaczenia pokrewne, ,należy je wszakże wyraźnie odróżniać” (Langacker 2008: rozdz. 9, przyp. 1).

\section{Źródło}

Tekst ten został po raz pierwszy opublikowany w roku $2012 \mathrm{w}$ pracy pt.:

Termin wjęzykoznawstwie, Język a komunikacja 31 pod red. Doroty Brzozowskiej i Władysława Chłopickiego. Kraków: Tertium; 65-73.

\section{Bibliografia}

Akmajian, Adrian, Richard A. Demers, Ann K. Farmer, Robert M. Harnish ([2001] 2010) An Linguistics. Introduction to Language and Communication. Cambridge, Mass.: MIT. Fromkin, Victoria, Robert Rodman, Nina Hyams ([1998] 2010) An Introduction to Language, Boston: Wadsworth Publishing.

Furdal, Antoni ([1990] 2000) Językoznawstwo otwarte. Wrocław: Zakład Narodowy im. Ossolińskich.

Grzegorczykowa, Renata (2007) Wstęp do językoznawstwa. Warszawa: PWN.

Langacker, Ronald W. (1987) Foundations of Cognitive Grammar, Part 1: Theoretical Prerequisites. Stanford: Stanford University Press.

Langacker, Ronald W. (2008) Cognitive Grammar: A Basic Introduction. Oxford: Oxford University Press.

Łozowski, Przemysław (2006) „Podobieństwo jako przejaw niedowolności (niearbitralności) znaku językowego". [W:] Henryk Kardela, Zbysław Muszyński, Maciej Rajewski (red.) Podobieństwo. RRR Kognitywistyka 2. Lublin: Wydawnictwo UMCS; 131-142.

Łozowski, Przemysław (2008) „Od dziecka do człowieka, czyli ‘być mężczyzną’ w słownikach”. [W:] Andrzej Radomski, Bogumiła Truchlińska (red.) Messkość w kulturze współczesnej. Lublin: Wydawnictwo UMCS; 428-435. 
Łozowski, Przemysław (2011) „Tradycja jako panchronia, czyli w poszukiwaniu ciągłości kultury”, [W:] Jan Adamowski, Marta Wójcicka (red.) Tradycja dla współczesności, t. 4. Lublin: Wydawnictwo UMCS; 113-123.

Łuczyński, Edward, Jolanta Maćkiewicz ([2001] 2006) Językoznawstwo ogólne. Wybrane zagadnienia. Gdańsk: Wydawnictwo Uniwersytetu Gdańskiego.

Mairal, Ricardo, Juana Gil (2006) “A First Look at Universals.“ [W:] Linguistic Universals, (red.) Ricardo Mairal, Juana Gil. Cambridge: Cambridge University Press; 1-45.

Milewski, Tadeusz ([1965] 2004) Językoznawstwo. Warszawa: Wydawnictwo Naukowe PWN.

Saussure, de Ferdinand ([1961] 1991) Kurs językoznawstwa ogólnego [Cours de linguistique générale. Paris: Editions Payot \& Rivages] (tłum.) Krystyna Kasprzyk. Warszawa: PWN.

Szacki, Jerzy (1984) „Słowo wstępne”. [W:] Jerzy Szacki (red.), Tradycja i nowoczesność. Warszawa: Czytelnik; 5-13.

Yule, George ([1985] 2010) The Study of Language. Cambridge: Cambridge University Press. 